\title{
Involvement of the CD95 (APO-1/Fas) Receptor and Ligand System in Helicobacter pylori-induced Gastric Epithelial Apoptosis
}

\author{
Jochen Rudi, ${ }^{*}$ Dirk Kuck,, ${ }^{\star}$ Susanne Strand, ${ }^{\star}$ Axel von Herbay, ${ }^{\ddagger}$ Sara M. Mariani, ${ }^{\S}$ Peter H. Krammer, ${ }^{\S}$ Peter R. Galle, \\ and Wolfgang Stremmel* \\ *Department of Medicine, Division of Gastroenterology, University of Heidelberg, ${ }^{\ddagger}$ Institute of Pathology, University of Heidelberg, and \\ ${ }^{\S}$ Tumorimmunology Program, German Cancer Research Center, Heidelberg, Germany
}

\begin{abstract}
Helicobacter pylori infection is associated with chronic gastritis, peptic ulceration, and gastric carcinoma. The potential role of CD95-mediated apoptosis was investigated in a panel of gastric biopsies obtained from patients with $H$. pylori-associated chronic gastritis $(n=29)$ and with noninfected normal mucosa $(n=10)$. Immunohistochemistry revealed increased CD95 receptor expression in epithelial and lamina propria cells in chronic gastritis. By in situ hybridization, CD95 ligand mRNA was absent or low in normal mucosa but expressed at high levels in lamina propria lymphocytes and, unexpectedly, in epithelial cells in chronic gastritis. Apoptotic cells were rare in normal mucosa but were observed regularly in chronic gastritis in close proximity to CD95 ligand mRNA expression throughout the epithelial and lamina propria cells.

In a functional analysis gastric epithelial cell lines were incubated with supernatants of $H$. pylori. Treatment with the cytotoxic isolate $H$. pylori 60190 but not with the noncytotoxic isolate Tx30a upregulated CD95 in up to $50 \%$ of gastric epithelial cells and induced apoptosis in these cells. $H$. pylori-induced apoptosis was partially prevented by blocking CD95, demonstrating the functional role of the CD95 system. These findings suggest that $H$. pylori-associated chronic gastritis involves apoptosis of gastric epithelial cells by activation of the CD95 receptor and ligand system. (J. Clin. Invest. 1998. 102:1506-1514.) Key words: Helicobacter pylori-associated chronic gastritis - gastric epithelial cell line - lymphoma cell line - fluorescence-activated cell scanning • in situ hybridization
\end{abstract}

\section{Introduction}

Helicobacter pylori is an important etiologic factor in the development of chronic gastritis and ulcer disease (1). Infection with this bacterium induces infiltration of the mucosa with in-

J. Rudi and D. Kuck contributed equally to this study.

Address correspondence to Dr. Jochen Rudi, Department of Medicine, Division of Gastroenterology, University of Heidelberg, Bergheimerstr. 58, 69115 Heidelberg, Germany. Phone: 49-6221-568611; FAX: 49-6221-565255; E-mail: jochen_rudi@ukl.uni-heidelberg.de Susanne Strand and Peter R. Galle's present address is the Department of Internal Medicine, University of Mainz, Mainz, Germany.

Received for publication 14 January 1998 and accepted for publication 1 September 1998.

J. Clin. Invest.

(C) The American Society for Clinical Investigation, Inc. 0021-9738/98/10/1506/09 \$2.00

Volume 102, Number 8, October 1998, 1506-1514

http://www.jci.org flammatory cells $(2,3)$. In $H$. pylori-induced chronic gastritis, surface epithelial damage, erosions, and atrophy of the gastric mucosa as well as increased epithelial proliferation are striking histological features $(3,4)$. Epithelial proliferation does not seem to be counterbalanced by epithelial necrosis in $H$. pyloriinduced gastritis (5), suggesting that apoptosis may account for the apparent cell loss in chronic gastritis.

Apoptosis, programmed cell death, is essential in development and homeostasis of multicellular organisms (for reviews see references 6-8). In addition it may also serve as a defense mechanism against bacterial and viral infections (9-11). Cytotoxic $\mathrm{T}$ lymphocytes and natural killer cells eliminate their targets by induction of apoptosis (12-16). Apoptosis can be mediated through activation of the CD95 receptor $(\mathrm{CD} 95)^{1}$ (APO-1/Fas) and ligand system. The CD95 belongs to the TNF receptor/nerve growth receptor superfamily and is a type I transmembrane protein $(17,18)$. CD95 is constitutively expressed in a wide range of tissues (19). CD95 ligand (CD95L) or agonistic antibodies induce apoptosis via $\operatorname{CD} 95(20,21)$. CD95L belongs to the TNF family, is a type II transmembrane protein (22), and is expressed in various cells and tissues, including activated $\mathrm{T}$ lymphocytes, testis, lung, kidney, and liver of patients with alcoholic liver damage (22-24). The CD95 receptor and ligand system mediates T cell cytotoxicity (13-15).

In $H$. pylori-induced chronic gastritis, we hypothesized that increased epithelial proliferation may be accompanied by epithelial apoptosis to maintain cellular homeostasis. We found that apoptosis of gastric epithelium was increased in $H$. pylori-associated gastritis and involved upregulation of CD95 expression and increase in CD95L expression in lymphocytes and gastric epithelial cells. Subsequent cell culture studies confirmed that $H$. pylori-induced apoptosis is mediated by activation of the CD95 receptor and ligand system in gastric epithelial cells.

\section{Methods}

\section{Patients}

Gastric biopsy specimens were taken from the antrum in a series of consecutive patients who underwent upper gastrointestinal endoscopy for diagnostic reasons. 29 patients with $H$. pylori-positive chronic gastritis (age, 25-88 yr; median age 54 yr; 19 males) and 10 patients with non-ulcer dyspepsia who showed histologic normal mucosa and were not infected with $H$. pylori (age, 23-68 yr; median age $48 \mathrm{yr}$; 4 males) were included (Table I). All patients gave informed consent to biopsy sampling. The study was approved by the Ethics Committee of the University of Heidelberg.

1. Abbreviations used in this paper: $c a g A / \mathrm{CagA}$, cytotoxin-associated gene/protein; CD95, CD95 receptor; CD95L, CD95 ligand; DAPI, 4',6-diamidino-2-phenylindole; TUNEL, terminal deoxynucleotidyl transferase-mediated deoxyuridine triphosphate nick-end labeling; $v a c A / \mathrm{VacA}$, vacuolating cytotoxin gene/vacuolating cytotoxin. 
Table I. Assessment of Gastritis, Apoptosis, and CD95-CD95L mRNA Expression in H. pylori-positive and-negative Antral Biopsies

\begin{tabular}{lccc}
\hline & $\begin{array}{c}\text { H.pylori- } \\
\text { negative nor- } \\
\text { mal mucosa }\end{array}$ & $\begin{array}{c}\text { H. pylori- } \\
\text { associated } \\
\text { gastritis }\end{array}$ & P value \\
\hline & $n=10$ & $n=29$ & \\
& & & \\
Gastritis* & $0.1(0.2)$ & $1.7(0.7)$ & $<0.0001$ \\
$\quad$ Chronic infammation & 0 & $0.8(0.9)$ & 0.009 \\
$\quad$ Activity & & & \\
Apoptosis & & & \\
$\quad$ Number of positive cells (\%) & $1.9(2.3)$ & $8.0(5.1)$ & 0.002 \\
CD95 expression & & & \\
$\quad$ Superficial epithelial cells (\%) & $0.8(2.1)$ & $30.0(31.1)$ & 0.003 \\
$\quad$ Pyloric gland cells (\%) & $53.0(24.3)$ & $76.1(14.2)$ & 0.018 \\
$\quad$ Lamina propria cells (\%) & $6.4(5.2)$ & $40.6(27.5)$ & 0.0002 \\
CD95L mRNA expression & $0.3(0.6)$ & $1.4(1.1)$ & 0.012 \\
& & & \\
\hline
\end{tabular}

The data are given as means $( \pm \mathrm{SD})$. Differences were calculated by Wilcoxon two-sample test. *The degree of histological gastritis was scored according to the updated Sydney classification (3). "For assessment of apoptosis and CD95 expression, at least 300 cells were counted in each section and the number of positive cells per 100 cells was expressed as a percentage. In some biopsies from patients with normal $H$. pylori-negative mucosa, $<300$ lymphocytes in each section were present. ${ }^{~}$ Scoring of CD95L mRNA was performed as described in the text.

\section{Gastric biopsies}

The specimens were immediately snap-frozen in liquid nitrogen and stored at $-80^{\circ} \mathrm{C}$ until analysis. Serial cryosections (4-5 $\mu \mathrm{m}$ thick) were fixed immediately for $5 \mathrm{~min}$ in cold acetone, air-dried overnight, and then stained with hematoxylin and eosin, and used for CD95 immunohistochemistry or stored at $-80^{\circ} \mathrm{C}$ until use. For in situ hybridization cryosections were fixed with $4 \%$ paraformaldehyde. The diagnosis of active and chronic gastritis was based on the updated Sydney system (3) by histological determination of the density of infiltration with neutrophils ( 0 , no infiltration; 1 , mild; 2 , moderate; and 3 , marked infiltration) and mononuclear cells ( 0 , no infiltration; 1 , mild; 2, moderate; 3 , marked infiltration). The presence of $H$. pylori in parallel biopsy samples was confirmed by the urease test and PCR of the 16S rRNA gene and the vacA gene of $H$. pylori as described previously $(25,26)$.

\section{Detection of apoptosis in gastric biopsies}

For identification of apoptotic cells, staining with 4',6-diamidino2-phenylindole (DAPI, $0.1 \mu \mathrm{g} / \mathrm{ml}$; Boehringer Mannheim, Mannheim, Germany) was performed according to the manufacturer's protocol. Slides were mounted with Permafluor Mounting medium (Immunotech, Marseille, France) and viewed under a microscope (Axiophot, Zeiss, Göttingen, Germany).

DNA staining with the terminal deoxynucleotidyl transferasemediated deoxyuridine triphosphate nick-end labeling (TUNEL) assay was performed with the In Situ Cell Death Detection kit (Boehringer Mannheim). In brief, the tissue was permeabilized with $0.1 \%$ Triton $\mathrm{X}$ and $0.1 \%$ sodium citrate in PBS and then incubated with 50 $\mu l$ TUNEL reaction mixture at $37^{\circ} \mathrm{C}$ for $1 \mathrm{~h}$. At least 300 cells were counted in each section and the number of TUNEL-positive apoptotic cells per 100 cells was expressed as apoptotic index in percent.

Detection of CD95 in gastric biopsies by immunohistochemistry

Detection of CD95 was performed using a monoclonal $\mathrm{IgG}_{1}$ mouse antibody directed against CD95 $(19,27)$. Acetone-fixed cryosections were incubated for $60 \mathrm{~min}$ at room temperature with the primary monoclonal antibody at a concentration of $10 \mu \mathrm{g} / \mathrm{ml}$. Bound monoclonal antibody was visualized by the avidin-biotin-peroxidase method using the Vectastain Elite ABC kit (Vector Laboratories, Burlingame, CA) and 3-amino-9-ethylcarbazol as chromogen. Counterstaining was performed with hemalaun (Merck, Darmstadt, Germany). CD95 expression was assessed by counting at least 300 epithelial cells or lymphocytes in each section. The number of CD95positive cells per 100 cells was expressed in percent. However, in some biopsies from patients with normal $H$. pylori-negative mucosa $<300$ lymphocytes in each section were present.

\section{In situ hybridization of CD95L mRNA in gastric biopsies}

Paraformaldehyde-fixed cryosections were dehydrated through an ascending series of ethanol and air dried. Digoxigenin-labeled antisense RNA corresponding to the sequence coding for amino acids 100-246 of human CD95L was generated by in vitro transcription with T7 polymerase (Boehringer Mannheim). The length was reduced to $\sim 250$ nucleotide fragments by limited alkaline hydrolysis (28). The hybridization mixture contained $100 \mathrm{pg} / \mu$ l digoxigeninlabeled RNA, $50 \%$ deionized formamide, $10 \%$ dextran sulfate, $2 \times$ SSC, $1 \times$ Denhardt's mixture $(0.02 \% \mathrm{wt} / \mathrm{vol}), 0.1 \%$ sodium dodecylsulfate, $500 \mu \mathrm{g} / \mathrm{ml}$ yeast tRNA, and $100 \mu \mathrm{g} / \mathrm{ml}$ herring sperm DNA. The pretreated, dried sections were incubated with this mixture and covered with parafilm. The slides were then incubated overnight at $37^{\circ} \mathrm{C}$ in a moist chamber containing $50 \%$ formamide. Subsequently, the slides were washed with $2 \times$ SSC $(30 \mathrm{~min})$, digested with $5 \mu \mathrm{g}$ RNase A (20 min), and again washed with $0.5 \times \operatorname{SSC}(20 \mathrm{~min})$ at $37^{\circ} \mathrm{C}$. Digoxigenin-labeled RNA was detected by a polyclonal antidigoxigenin sheep antibody conjugated with alkaline phosphatase (Boehringer Mannheim) and visualized for fluorescence microscopy using 2-hydroxy-3-naphthoic-acid-2'-phenylanilide phosphate (HNPP; Boehringer Mannheim) as chromogenic substrate. Subsequent staining with TUNEL or DAPI was performed as described in order to localize CD95L mRNA expression within the gastric mucosa. The slides were then viewed under a fluorescence microscope (Axiophot, Zeiss). CD95L mRNA expression was scored semiquantitatively ( 0 , no expression; 1 , mild; 2 , moderate; 3 , marked expression).

H. pylori strains, gastric epithelial cell lines, and human lymphoma cell lines

Two different H. pylori strains, H. pylori 60190 (ATCC 49503), a wild-type cytotoxic, $\operatorname{cag} A$-positive strain with the $v a c A$ genotype s1a/ $\mathrm{m} 1$, and Tx30a, a noncytotoxic strain, which has the $v a c A$ genotype $\mathrm{s} 2 / \mathrm{m} 2$ and is $\operatorname{cag} A$ negative, were used (29). The strains were cultured in medium containing $10 \%$ brain heart infusion, $10 \%$ Brucella broth, $70 \%$ RPMI 1640, and 10\% FCS for $3 \mathrm{~d}$ under microaerophilic conditions at $37^{\circ} \mathrm{C}$. Supernatants were prepared by centrifugation $(2,000 \mathrm{~g}$ at $4^{\circ} \mathrm{C}$ ) and filtration through a $0.2-\mu \mathrm{m}$ filter and then stored at $-20^{\circ} \mathrm{C}$.

Three gastric cancer cell lines, AGS (ATCC CRL 1739), Kato III (ATCC HTB 103), and Hs 746T (ATCC HTB 135) were cultured in Ham's F12 medium, RPMI 1640, or Dulbecco's modified Eagle medium (BioWhittaker, Walkersville, MD), supplemented with $10 \%$ FCS, $5 \mathrm{mmol} /$ liter glutamine (Flow Laboratories, Meckenheim, Germany), $100 \mu \mathrm{g} / \mathrm{ml}$ streptomycin, and $100 \mu \mathrm{g} / \mathrm{ml}$ penicillin (both Flow Laboratories). The human lymphoma cell lines Jurkat ${ }^{\mathrm{s}}$, which is sensitive to CD95-mediated apoptosis, and Jurkat ${ }^{\mathrm{R}}$, which is insensitive to CD95-mediated apoptosis, were grown in Iscove's modified Dulbecco's medium supplemented with 10\% FCS (30). Gastric cancer cells and lymphoma cells were subconfluently seeded in $25-\mathrm{cm}^{2}$ culture flasks and incubated with $\mathrm{H}$. pylori supernatants at $37^{\circ} \mathrm{C}$ in $5 \%$ $\mathrm{CO}_{2}$ in air.

\section{Cytotoxicity assay}

The cultured epithelial cell lines, AGS, Kato III, and Hs 746T were seeded into 96 -well plates $\left(10^{5}\right.$ cells/well $)$ for $24 \mathrm{~h}$. Then, serial dilutions of culture supernatants of H.pylori 60190 or Tx30a were added to the cells and incubated up to $24 \mathrm{~h}$ at $37^{\circ} \mathrm{C}$. Experiments were per- 
formed in quadruplicate and were repeated twice. After removal of the medium, the remaining adherent cells were stained with $0.75 \%$ crystal violet solution in $50 \%$ methanol. Cell viability was quantified by eluting the dye from the stained cells with $0.1 \mathrm{M}$ sodium citrate/ $0.1 \mathrm{M}$ citric acid and $50 \%$ ethanol. Absorbance was measured at 540 nm (31).

\section{Detection of apoptosis in gastric cells and in lymphoma cells}

$F A C S^{\circledR}$ analysis. Apoptosis in gastric epithelial cells and in lymphoma cells was assessed by FACS ${ }^{\circledR}$ analysis carried out in a FACScan ${ }^{\circledR}$ flow cytometer (Becton Dickinson, Heidelberg, Germany). Cells floating in the culture medium were collected by centrifugation at $100 \mathrm{~g}$. Adherent cells were harvested by incubation with $1 \%$ trypsin for 2 min. The cells were washed with PBS, fixed in $70 \%$ ethanol, and stained with propidium iodide $(50 \mu \mathrm{g} / \mathrm{ml}$ in PBS). DNA fluorescence was determined by FACScan ${ }^{\circledR}$ analysis according to the method of Nicoletti et al. (32) using LYSIS II software (Becton Dickinson). A minimum of 10,000 events was measured per sample.

DAPI and TUNEL staining. For DAPI staining of cellular DNA, cultured gastric epithelial cells were plated on chamber slides (LabTek; Nunc, Naperville, IL). After removal of the culture medium, cells were briefly dipped twice into PBS containing $1 \mathrm{mM} \mathrm{MgCl}_{2}$ at $37^{\circ} \mathrm{C}$. The slides were then fixed in methanol for $10 \mathrm{~min}$ followed by acetone for $5 \mathrm{~min}$ at $-20^{\circ} \mathrm{C}$ and air dried. DNA staining with DAPI and with TUNEL reagent was performed according to the manufacturer's protocols (Boehringer Mannheim) as described above. The slides were viewed under a fluorescence microscope.

\section{CD95 expression on gastric cells}

CD95 expression on the cell surface of cultured gastric epithelial cells was assessed by FACS $^{\circledR}$ analysis. A mouse anti-APO-1 IgG $_{1}$ antibody $(100 \mathrm{ng} / \mathrm{ml})$ was used as primary antibody (27). Phycoerythrin labeled goat anti-mouse antibody (Jackson ImmunoResearch, West Grove, PA) was used as secondary reagent for indirect immunofluorescence according to the manufacturer's instructions. Gastric epithelial cells were washed with PBS and incubated with anti-APO-1 antibody. After a 15-min incubation, cells were washed twice, incubated for 15 min with the secondary antibody, washed twice, resuspended in PBS containing $1 \%$ formaldehyde at $4^{\circ} \mathrm{C}$, and assayed by $\mathrm{FACS}^{\circledR}$ analysis. For data acquisition a gate was set on intact cells by forward/ side scatter analysis and a minimum of 10,000 viable cells was analyzed.

Treatment with $\mathrm{IgG}_{3}$ anti-APO-1 antibody and $\mathrm{F}\left(a b^{\prime}\right)_{2}$ anti-APO-1 fragments

To investigate the susceptibility of gastric epithelial cells to undergo apoptosis upon CD95 stimulation, cells were treated for $12-48 \mathrm{~h}$ after plating with the monoclonal antibody $\mathrm{IgG}_{3}$ anti-APO-1 at a concentration of $1 \mu \mathrm{g} / \mathrm{ml}(20,27)$. CD95 blocking experiments were performed by incubation with $\mathrm{F}\left(\mathrm{ab}^{\prime}\right)_{2}$ anti-APO- 1 fragments as described previously (33). Experiments were performed at least three times.

\section{RT-PCR analysis of CD95 $\mathrm{mRNA}$ and CD95 L $\mathrm{mRNA}$}

RNA was prepared from $\sim 10^{7}$ cultured AGS, Kato III, or Hs $746 \mathrm{~T}$ cells treated with $H$. pylori supernatants $(100 \mu \mathrm{l} / \mathrm{ml})$ for $24 \mathrm{~h}$, using the RNeasy kit (Qiagen, Hilden, Germany) according to the manufacturer's instruction. RT-PCR was performed using the GeneAmp RNA PCR kit (Perkin Elmer, Norwalk, CT) according to the manufacturer's protocol. cDNA synthesis was performed with oligo $\mathrm{d}(\mathrm{T})_{16}$ in the presence of $75 \mathrm{U}$ MuLV RT (Perkin Elmer), $67 \mu \mathrm{mol} \mathrm{MgCl}_{2}$, and $63 \mu \mathrm{M}$ of each dNTP in $20 \mu \mathrm{l}$ for $45 \mathrm{~min}$ at $42^{\circ} \mathrm{C}$. The efficiency of the reverse transcriptase and the integrity of RNA used in the RTPCR were controlled by detection of human $\beta$-actin mRNA. For amplification of CD95 DNA, the primers 5' TGA AGT TGA TGC CAA TTA CG $3^{\prime}$ and 5' CAA GTG CAG ATG TAA AC 3' were used. The primers used for amplification of the CD95L have been described previously (30). 35 PCR cycles were performed at $94^{\circ} \mathrm{C}$ for
$30 \mathrm{~s}$, at $56^{\circ} \mathrm{C}$ for $30 \mathrm{~s}$, and at $72^{\circ} \mathrm{C}$ for $2 \mathrm{~min}$ in a volume of $100 \mu \mathrm{l}$. PCR-amplified products (10 $\mu \mathrm{l}$ each) were analyzed on $1.5 \%$ agarose gels after ethidium bromide staining.

\section{Results}

Detection of apoptosis in gastric biopsies. A high number of TUNEL-positive apoptotic cells was found in antral samples in $24(82.8 \%)$ of 29 patients with $H$. pylori-associated gastritis (Table I). The apoptotic index in biopsies from all $H$. pyloriinfected patients was $8.0 \pm 5.1 \%(P=0.002)$. Apoptotic cells were present in the superficial epithelial cells, in the pyloric gland cells, and in the lamina propria. As shown in Fig. 1, apoptotic cells were typically localized in the neighborhood of CD95L mRNA-positive cells. In contrast, samples from $H$. $p y$ lori-negative patients showed no apoptotic TUNEL-positive cells in 7 of 10 patients. Only a small number of apoptotic epithelial cells was found in the pyloric gland cells and lamina propria cells in biopsies of the other three patients. The apoptotic index in biopsies from all patients without $H$. pylori infection was $1.9 \pm 2.3 \%$.

CD95 expression in gastric biopsies. The above patients were studied for expression of CD95 in antral biopsies (Fig. 2). In all biopsies with $H$. pylori-associated gastritis, CD95 expression on surface epithelium was significantly increased $(30.0 \pm 31.1 \%, P=0.003$; Table I). Lamina propria cells displayed CD95 expression in $40.6 \pm 27.5 \%$ of the cells $(P=$ 0.0002). In contrast, in H. pylori-negative biopsies CD95 expression was detected only on a few surface epithelial cells $(0.8 \pm 2.1 \%)$. Lamina propria cells showed low CD95 expression $(6.4 \pm 5.2 \%)$. In pyloric gland cells strong expression of CD95 was found in both $H$. pylori-positive and $H$. pylori-negative biopsies, but it was more pronounced in chronic gastritis (76.1 \pm 14.2 vs. $53.0 \pm 24.3 \% ; P=0.018$ ). These findings suggest that CD95 expression is upregulated in $H$. pylori-induced chronic gastritis.

CD95L mRNA expression in gastric biopsies. To assess whether CD95L is expressed in H. pylori-associated chronic gastritis, CD95L mRNA was investigated by in situ hybridization. In $21(72.4 \%)$ of $29 \mathrm{H}$. pylori-infected patients, antral biopsies showed moderate or intense expression of CD95L mRNA (Fig. 1), located in the lamina propria (Fig. 3), thus, in the area of infiltration with mononuclear cells. In addition, CD95L mRNA was also localized in superficial epithelial cells and pyloric gland cells, demonstrating that gastric epithelial cells are capable of expressing CD95L mRNA in H. pyloriassociated chronic gastritis. Uniformly, CD95L mRNA expression by epithelial cells was in the same range as the expression by lamina propria cells. The mean score of CD95L mRNA expression in biopsies from all $H$. pylori-infected patients was $1.4 \pm 1.1(P=0.012$; Table $\mathrm{I})$. CD95L mRNA expression was absent or low in biopsies from patients without $H$. pylori-associated gastritis (score, $0.3 \pm 0.6$ ). These results indicate that CD95L mRNA expression is not restricted to lymphocytes but can also be expressed by gastric epithelial cells.

Induction of apoptosis and cytolysis in gastric epithelial cell lines. In addition to the above in vivo experiments, induction of apoptosis was evaluated in vitro in the three different gastric epithelial cell lines AGS, Kato III, and Hs 746T by treating with supernatants of the H.pylori strains 60190 (cytotoxic) and Tx30a (noncytotoxic). FACS ${ }^{\circledR}$ analysis after propidium iodide staining (Fig. 4, $A$ and $B$ ) and staining with TUNEL or DAPI 

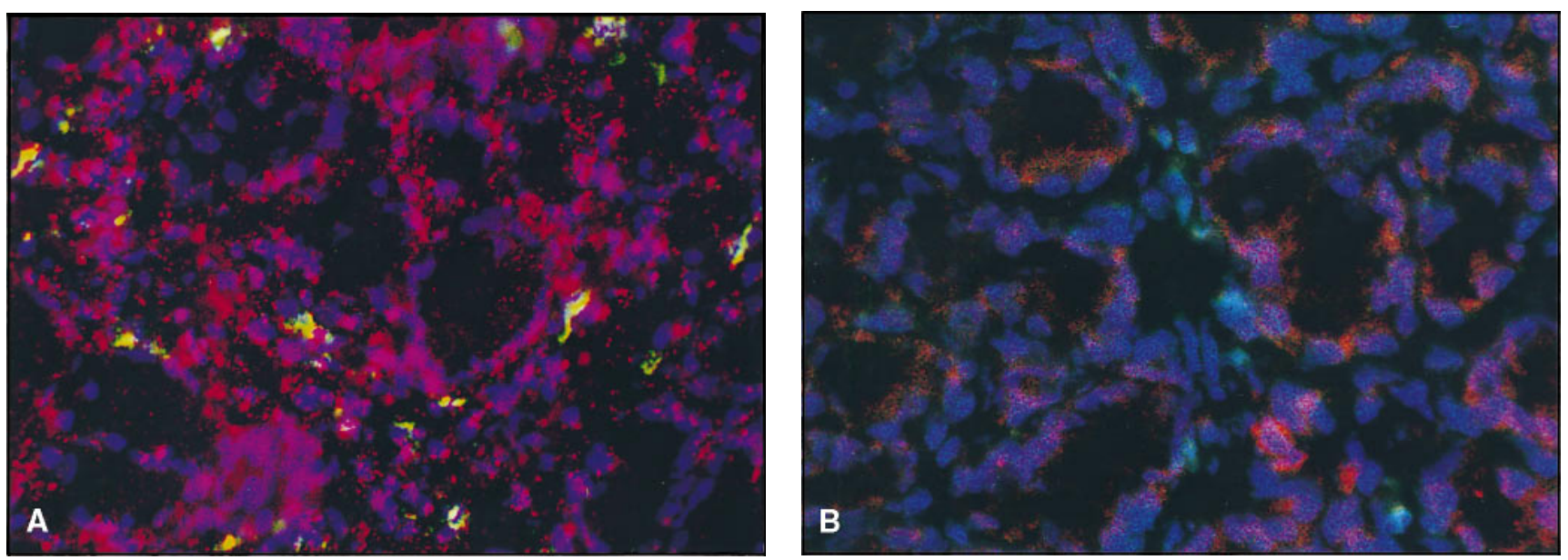

Figure 1. (A) Detection of apoptotic cells by TUNEL staining (green fluorescence) and in situ hybridization for CD95L mRNA (red staining) in H. pylori-associated chronic antral gastritis. Nuclei are stained blue by DAPI. Note that apoptotic cells are localized next to the CD95L signal. $(B)$ Normal mucosa with few apoptotic cells and low levels of CD95L mRNA expression. $\times 300$.

reagents (not shown) demonstrated apoptosis as the predominant form of cell death in a dose- and time-dependent fashion after incubation of all three cell lines with H. pylori 60190 supernatant. Apoptosis, as detected by the appearance of a typical sub-G1 fraction of fragmented nuclei in the FACS ${ }^{\circledR}$ analysis, started after $2 \mathrm{~h}$ of incubation with H. pylori 60190 supernatant amounting to up to $30 \%$ in AGS cells, $49 \%$ in Kato III cells (Fig. $4 \mathrm{~B}$ ), and $34 \%$ in Hs $746 \mathrm{~T}$ cells (not shown) at $4-6 \mathrm{~h}$, and to $66 \%$ in AGS cells, $65 \%$ in Kato III cells, and $48 \%$ in Hs $746 \mathrm{~T}$ cells at $12 \mathrm{~h}$ (not shown). Comparable results were obtained by TUNEL and DAPI staining (not shown). When H.pylori 60190 supernatant was fractionated by ultrafiltration, the fraction containing bacterial products with a molecular mass $>50 \mathrm{kD}$ induced apoptosis in gastric epithelial cells. In contrast, no induction of apoptosis was seen after incubation of gastric epithelial cells using the fraction with bacterial products $<50 \mathrm{kD}$ (data not shown). Anti-APO-1 treatment resulted exclusively in apoptotic cell death as indicated by the sub-G1 peak in FACS ${ }^{\circledR}$ analysis (Fig. $4 A$ ). FACS ${ }^{\circledR}$ analysis after treatment with $H$. pylori 60190 supernatant revealed a minor fraction of very small nuclear fragments close to the $y$ axis in addition to the typical sub-G1 fraction (Fig. $4 A$ ), indicating that $H$. pylori induced cytolysis as well. Accordingly, apoptotic cell death and cytolysis accounted for complete cell death in all three cell lines after treatment with H. pylori 60190 for $12 \mathrm{~h}$ as assessed by the crystal violet assay (Fig. 5). In contrast, incubation of gastric epithelial cell lines with $H$. pylori strain Tx30a supernatant resulted in no or only a slight increase in apoptotic or necrotic cells compared with cells incubated with medium alone (Figs. 4 and 5).

These data show that H. pylori induces apoptotic and cytolytic cell death in gastric epithelial cell lines in vitro.

Upregulation of CD95 in gastric epithelial cell lines by $\mathrm{H}$. pylori. Untreated gastric epithelial cells showed a low basal expression of CD95 in 7\% or less of the cells (AGS cells, 7\%; Kato III cells, 5\%; and Hs 746T cells, 7\%) as detected by FACS $^{\circledR}$ analysis after phycoerythrin staining. Incubation with H. pylori 60190 supernatant resulted in a time-dependent, substantial increase in CD95-positive epithelial cells. CD95 expression was detectable in up to $50 \%$ of AGS cells, in $28 \%$ of Hs 746 T cells (Fig. 6), and in $25 \%$ of Kato III cells (not shown) after a 48-h treatment. In contrast, no or only slight upregula-
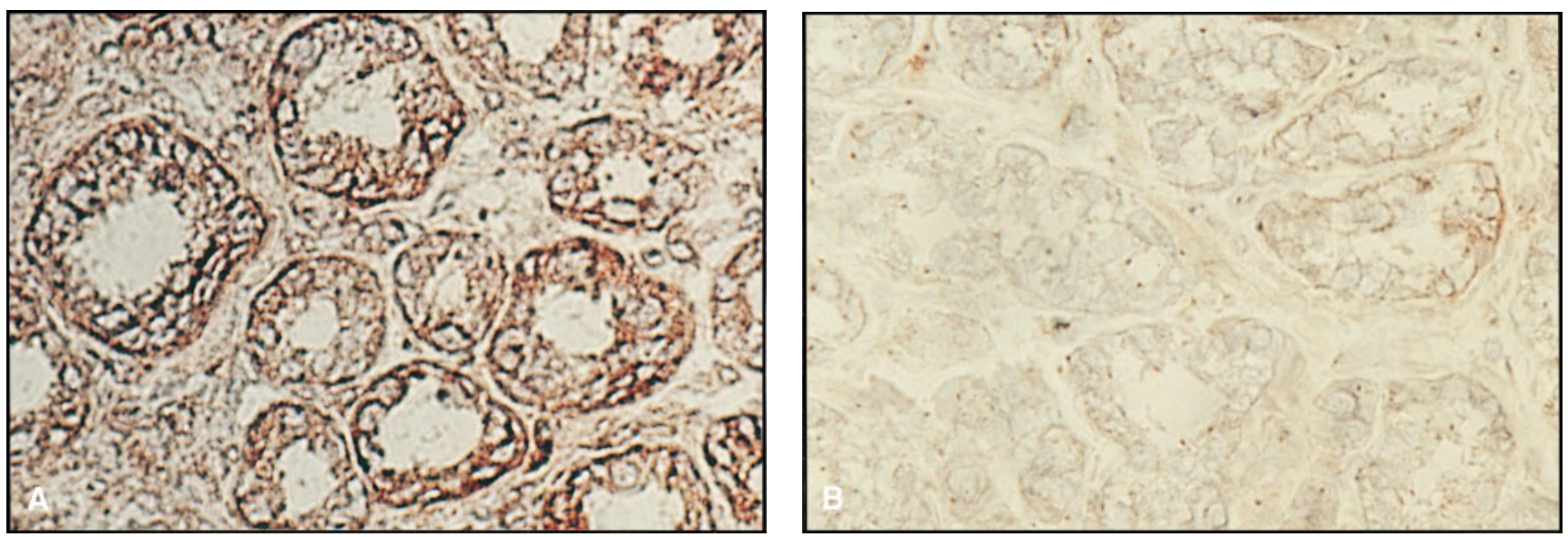

Figure 2. CD95 expression in antral mucosa by immunocytochemistry. Expression of CD95 at the surface of pyloric gland cells is significantly increased in $H$. pylori-associated chronic antral gastritis $(A)$ compared with uninfected normal mucosa $(B) . \times 400$. 
tion of CD95 in all three cancer cell lines was observed after treatment with supernatant of $H$. pylori strain Tx30a. In addition, incubation of gastric epithelial cells with TNF- $\alpha(0-50 \mathrm{ng} /$ $\mathrm{ml})$ or IFN- $\gamma(0$ to $250 \mathrm{U} / \mathrm{ml})$ or both had only slight or no effects on CD95 and CD95L expression in these cells (data not shown).

After incubation with $H$. pylori 60190 supernatant the percentage of cells expressing CD95 was lower than the percentage of cells undergoing apoptosis. This could be explained by the different doses of $H$. pylori supernatant used in the studies. Doses used for CD95 upregulation $(0-125 \mu \mathrm{l} / \mathrm{ml})$ were lower than those used for induction of apoptosis $(\geq 100 \mu \mathrm{l} / \mathrm{ml})$ in order to avoid apoptotic cell death within the incubation period.

CD95 mRNA was detectable by semiquantitative RT-PCR after treatment with $H$. pylori 60190 supernatant $(100 \mu \mathrm{l} / \mathrm{ml})$ for $24 \mathrm{~h}$ (not shown). No CD95 mRNA expression was found in untreated gastric epithelial cell lines or in epithelial cells treated by supernatant of strain Tx30a.

Thus, H. pylori 60190 increases CD95 expression at the mRNA and protein level.

Induction of CD95L mRNA expression in gastric epithelial cell lines by H. pylori. The unexpected finding of CD95L mRNA expression not only by lymphocytes but also by gastric epithelial cells in chronic gastritis prompted us to study the induction of CD95L mRNA in gastric epithelial cell lines in vitro after treatment with $H$. pylori. CD95L mRNA was constitutively expressed in untreated gastric epithelial cells. CD95L mRNA levels increased after incubation with H. pylori 60190 supernatant $(100 \mu \mathrm{l} / \mathrm{ml})$ reaching a maximum after $24 \mathrm{~h}$ (Fig. 7). In contrast, the amount of CD95L mRNA remained unchanged after incubation of gastric epithelial cells with supernatant of H. pylori strain Tx30a (Fig. 7) or with TNF- $\alpha$ and/or IFN- $\gamma$ (data not shown). These findings are consistent with the results obtained by in situ hybridization of CD95L mRNA showing increased expression of CD95L mRNA by gastric epithelial cells in biopsies of patients affected by chronic gastritis.

H. pylori-induced apoptosis is mediated by the CD95 receptor and ligand system. To further demonstrate the functional relevance of the CD95 receptor and ligand system in $H$. pylori-induced apoptosis, gastric epithelial cells were incubated with the agonistic anti-APO-1 antibody or with antagonistic $\mathrm{F}\left(\mathrm{ab}^{\prime}\right)_{2}$ anti-APO-1 fragments. In untreated gastric epithelial cells, incubation with anti-APO-1 antibody resulted in apoptotic cell death in up to $15 \%$ of the cells. However, when gastric epithelial cells were pretreated with sublethal doses of $H$. pylori 60190 supernatant $(100 \mu \mathrm{l} / \mathrm{ml})$ for $48 \mathrm{~h}$, additional stimulation with anti-APO-1 antibody $(1 \mu \mathrm{g} / \mathrm{ml})$ for $24 \mathrm{~h}$ induced apoptosis in up to 46 and $72 \%$ of the gastric epithelial cells, respectively (data not shown). In contrast, induction of apoptosis in untreated cells by $H$. pylori 60190 supernatant $(300 \mu \mathrm{l} / \mathrm{ml})$ was substantially inhibited from $62 \pm 6$ to $25 \pm 6 \%$ in AGS cells and from $53 \pm 6$ to $27 \pm 4 \%$ in Kato III cells after $24 \mathrm{~h}$ of culture in the presence of $\mathrm{F}\left(\mathrm{ab}^{\prime}\right)_{2}$ anti-APO- 1 fragments $(1 \mu \mathrm{g} / \mathrm{ml})$.

Incubation of apoptosis-sensitive Jurkat ${ }^{\mathrm{s}}$ cells for $12 \mathrm{~h}$ with culture supernatant from AGS cells pretreated with $H$. pylori 60190 supernatant $(100 \mu \mathrm{l} / \mathrm{ml})$ for $24 \mathrm{~h}$ induced apoptosis in $24 \%$ of the lymphocytes. In contrast, cultivation of CD95L insensitive Jurkat ${ }^{\mathrm{R}}$ cells resulted in a low level of apoptotic cell death $(<7 \%)$, which was comparable to the level of apoptosis seen in Jurkat ${ }^{\mathrm{S}}$ cells incubated with culture supernatants from untreated or with Tx30a supernatant-treated AGS cells or with supernatants from $H$. pylori 60190 or Tx30a (data not shown). This suggests that $H$. pylori 60190 induces CD95L expression in AGS cells leading to apoptosis in Jurkat ${ }^{\mathrm{s}}$ cells. Taken together, the results show that $H$. pylori-induced apoptosis in gastric epithelial cells is mediated by activation of the CD95 receptor and ligand system.

\section{Discussion}

In this study we demonstrate that $H$. pylori-associated chronic gastritis involves apoptotic cell death. A markedly elevated number of apoptotic cells was identified in surface epithelium, antral pyloric glands, and lamina propria in $83 \%$ of biopsies from patients with $H$. pylori-associated gastritis. Increased epithelial apoptosis has been reported in gastric biopsies from patients with duodenal ulcer and nonatrophic gastritis (3436). Successful treatment of $H$. pylori resulted in a decrease of apoptosis to levels found in normal mucosa (34). This implies that H. pylori induces gastric epithelial apoptosis.
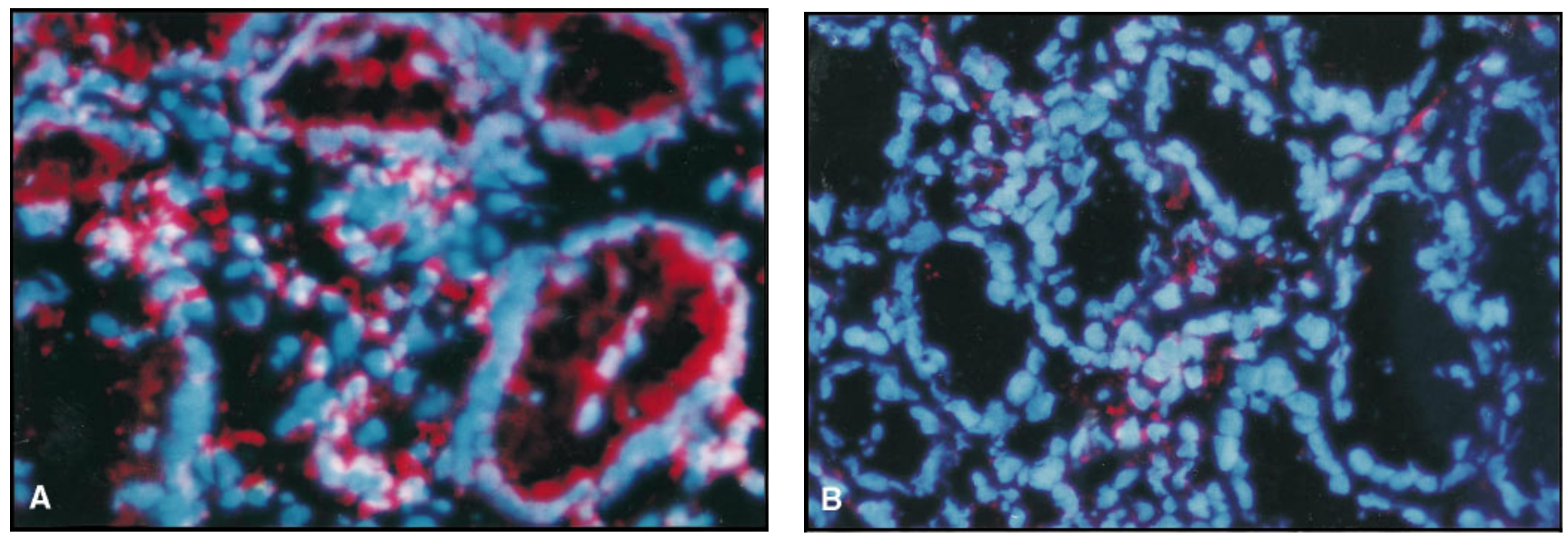

Figure 3. (A) DAPI staining and in situ hybridization for CD95L mRNA in H. pylori-associated chronic antral gastritis. Nuclei are stained blue and CD95L mRNA is indicated by red staining. CD95L mRNA is expressed extensively by epithelial gland cells and lamina propria lymphocytes. Lymphocytes are characterized by large nuclei and small cytoplasm. (B) Normal mucosa with low levels of CD95L mRNA expression. $\times 400$. 
A
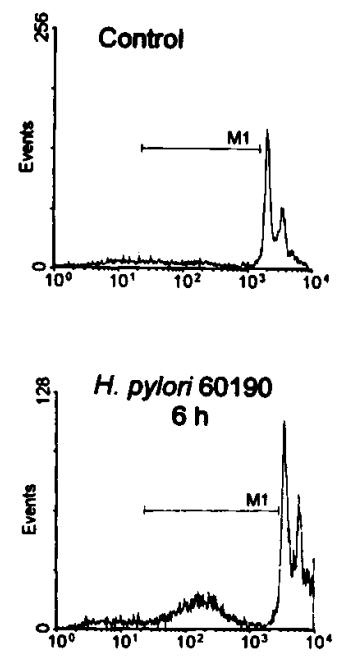

Log fluorescence
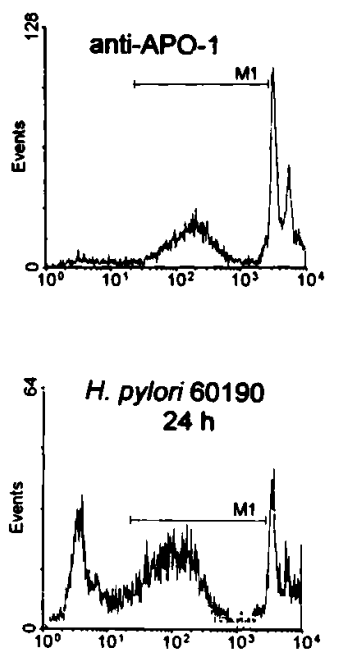

Log fiuorescence

B

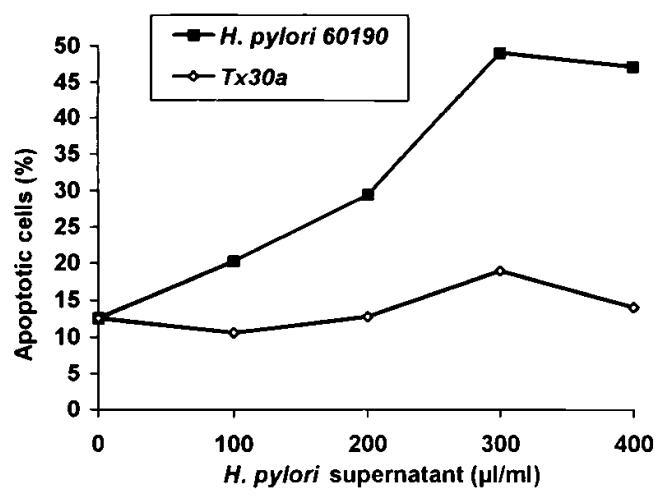

Kato III

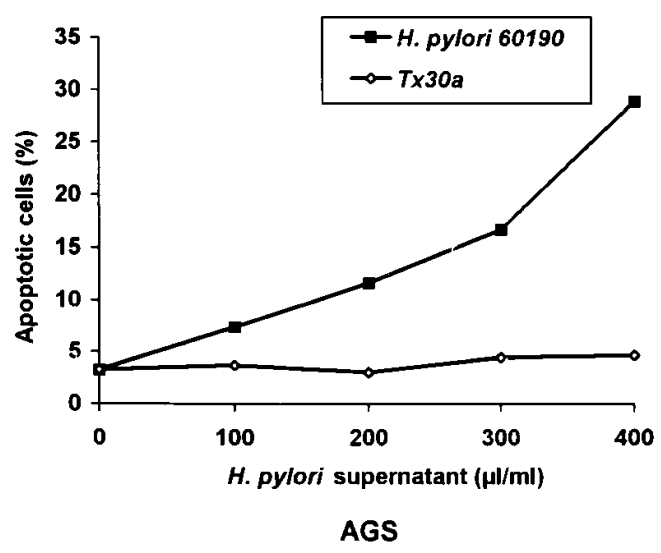

Figure 4. Dose-dependent induction of apoptosis in the gastric epithelial cell lines Kato III and AGS by supernatants of $H$. pylori strains 60190 and Tx30a. (A) Flow cytometry of untreated AGS epithelial cells (top left) and AGS epithelial cells treated with agonistic anti-APO-1 antibody $(1 \mu \mathrm{g} / \mathrm{ml})$ for $6 \mathrm{~h}$ (top right) or H. pylori 60190 supernatant $(300 \mu \mathrm{l} / \mathrm{ml})$ for $6 \mathrm{~h}$ (bottom left) and $24 \mathrm{~h}$ (bottom right). Apoptotic cells are characterized by a shift to the left representing the sub-G1 state of the cells (marker $M 1$ ). Note the increases in very

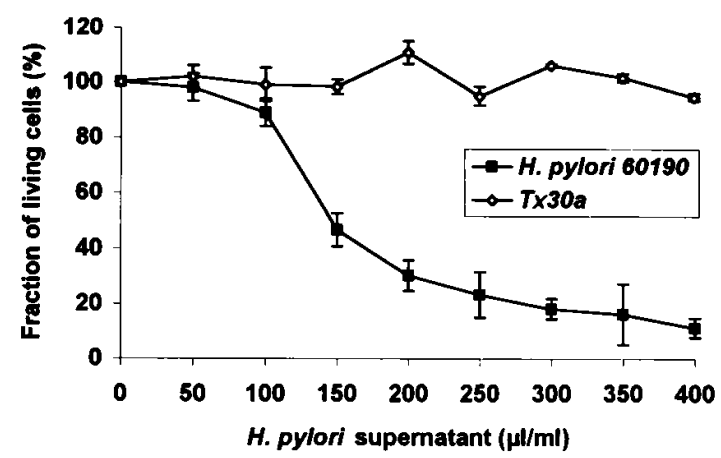

Kato III

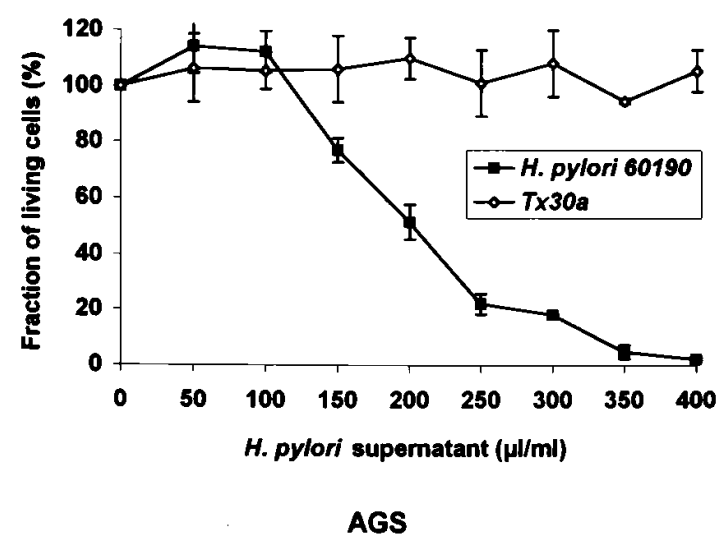

Figure 5. Cytotoxicity assay with crystal violet staining of viable cells. Kato III and AGS epithelial cells were incubated with different doses of supernatants obtained from strain H. pylori 60190 and strain Tx30a for $12 \mathrm{~h}$. Data are expressed as fraction of living cells (mean $\pm \mathrm{SD}$ ).

The mechanisms of apoptosis induction by $H$. pylori have not been evaluated. Our data suggest that apoptosis in $H$. pylori-associated gastritis involves CD95 and CD95L activation. In $H$. pylori-infected mucosa CD95 expression was upregulated in surface epithelium, lamina propria lymphocytes, and pyloric gland cells. In addition, increased levels of CD95L mRNA found by in situ hybridization in lamina propria cells suggest that lymphocytes in the lamina propria might express CD95L and induce apoptosis via CD95L in CD95-positive neighboring cells. Activated T cells express CD95L, and the CD95-CD95L system is one of the major pathways of $\mathrm{T}$ cellmediated cytotoxicity (13-15, 33, 37). CD95L-expressing lymphocytes play a key role in diseases with chronic inflammation such as chronic viral hepatitis B and C $(24,38)$. However, CD95L is not confined to the immune system, as thyrocytes from patients with Hashimoto's thyroiditis, hepatocytes from patients with alcoholic liver damage, or hepatoma cells express CD95L $(24,39,40)$. Interestingly, CD95L mRNA was also expressed on surface epithelium and pyloric gland cells of $H$. $p y$ -

small nuclear fragments close to the $y$ axis and at the left of marker M1 which represent additional nonapoptotic cell death after treatment with H. pylori 60190 for $24 \mathrm{~h}$. (B) Increase in the number of apoptotic Kato III and AGS cells after treatment with different doses of $H$. pylori supernatants for $6 \mathrm{~h}$ as determined by FACS ${ }^{\circledR}$ analysis. 

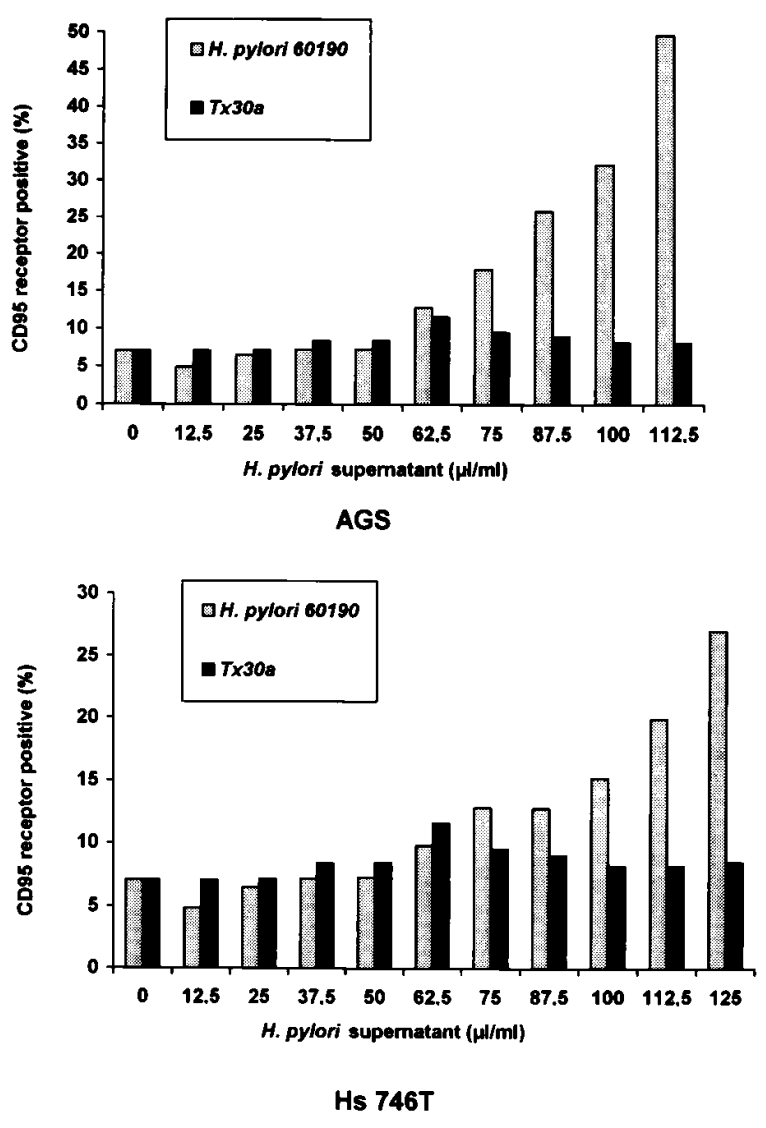

Figure 6. Upregulation of CD95 in gastric epithelial cells after treatment with $H$. pylori supernatant. CD95 expression as assessed by FACS $^{\circledR}$ analysis significantly increased after incubation of AGS and Hs 746T cells with supernatant of H. pylori 60190 for $48 \mathrm{~h}$.

lori-infected mucosa at levels comparable to those found on lamina propria lymphocytes. The presence of CD95L mRNA and upregulation of CD95 in the same cell points to a new mechanism of damage in $H$. pylori-induced chronic gastritis. By TUNEL staining, apoptotic cells were regularly detected in close proximity to CD95L mRNA-expressing cells. CD95L might be expressed as a membrane-bound form on epithelial cells and mediate apoptosis by "fratricide" interacting with CD95 on neighboring epithelial cells (41) or through suicide of the CD95L-CD95-expressing cell itself. Thus, gastric epithelial apoptosis in $H$. pylori-associated gastritis may be induced not only by CD95L-expressing lymphocytes but also by CD95Lexpressing epithelial cells.

The causative relationship between $H$. pylori, induction of apoptosis, and activation of the CD95 receptor and ligand system was further established in in vitro studies. Treatment with cytotoxic $H$. pylori supernatant induced mRNA production of CD95L and upregulated CD95 expression in gastric epithelial cells. Agonistic anti-APO-1 antibody induced apoptotic cell death in gastric epithelial cells pretreated with low concentrations of $H$. pylori supernatant, demonstrating functional CD95 expression. In contrast, incubation of gastric epithelial cells with cytotoxic $H$. pylori supernatant in the presence of $\mathrm{F}\left(\mathrm{ab}^{\prime}\right)_{2}$ anti-APO-1 fragments partially protected from induction of apoptosis. Cultivation of CD95L-sensitive Jurkat ${ }^{\mathrm{s}}$ cells with supernatants of AGS cells pretreated with H. pylori 60190 su-
CD95L mRNA

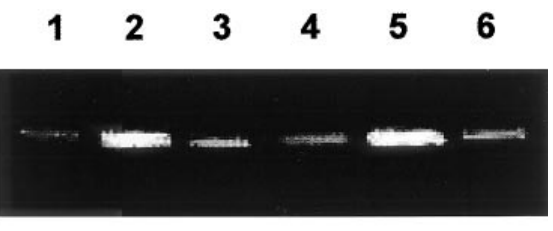

$\beta$-Actin mRNA

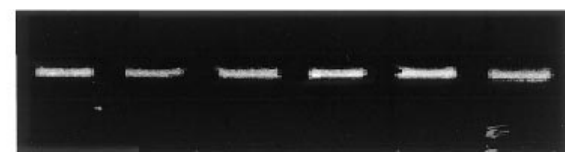

Figure 7. Semiquantitative RT-PCR analysis of CD95L mRNA expression after incubation with $H$. pylori supernatants $(100 \mu \mathrm{l} / \mathrm{ml})$ for 24 h. Incubation with H. pylori 60190 increased CD95L mRNA expression in AGS (lanes 1-3) and Kato III (lanes 4-6) cells. Expression of $\beta$-actin mRNA was used as control. Lanes: 1 and 4 , control; 2 and 5, H. pylori 60190; 3 and 6, H. pylori strain Tx30a.

pernatant resulted in apoptotic cell death of the lymphoma cells, suggesting CD95L expression of AGS cells by H. pylori. The activation of the CD95-CD95L system by $H$. pylori raises the question of whether this effect is specific for gastric epithelial cells. Parallel experiments with HeLa and HepG2 cells (data not shown) revealed that treatment with H. pylori 60190 supernatant resulted in a similar increase in sensitivity towards apoptosis and to induction of apoptosis arguing for a nonspecific effect of $H$. pylori on different cells.

These data strongly support the important pathogenic and functional role of the CD95 receptor and ligand system in $H$. pylori-induced apoptosis. H. pylori induced simultaneous expression of functional CD95L and CD95, possibly as the result of cytokine induction released from activated epithelial cells and/or infiltrating lymphocytes (42-44). However, TNF- $\alpha$ and/ or IFN- $\gamma$ had no or only slight effects on CD95-CD95L upregulation in gastric cancer cell lines in vitro (45). These findings may be cell line specific and do not necessarily exclude a possible upregulation of the CD95 system in gastric epithelial cells by infiltrating lymphocytes in vivo.

Upregulation of CD95 receptor expression and induction of apoptosis was achieved with the cytotoxic $H$. pylori strain 60190. Cytotoxic H. pylori strains produce high concentrations of $\mathrm{VacA}$ and induce vacuolation in gastric epithelial cells in vitro (46-48). These strains are more virulent and are associated with more severe disease such as peptic ulceration (29, 49). In addition, CagA producing $H$. pylori strains are associated with increased cytokine production in the gastric mucosa and in gastric epithelial cell lines (50-54), which may be responsible for activation of the CD95-CD95L system in these cells. In a recent study in rats lipopolysaccharide isolated from a cytotoxic $H$. pylori strain was suggested to be responsible for induction of apoptosis (55). However, whether cytokines or bacterial products from virulent $H$. pylori strains initiate CD95 activation in vivo is still elusive and needs further investigation.

Incubation of gastric epithelial cells with $H$. pylori supernatant in the presence of $\mathrm{F}\left(\mathrm{ab}^{\prime}\right)_{2}$ anti-APO- 1 fragments could not completely protect from apoptosis. In addition, the number of dead cells by the cytotoxicity assay was higher than the fraction of apoptotic cells measured by FACS ${ }^{\circledR}$ analysis, indicating that cytolytic cell death might also occur in addition to apoptosis. Cytolytic cell death is caused by the bacterial VacA 
protein, which induces vacuolar degeneration in gastric epithelial cells (46-49) probably via a V-ATPase proton pump (56). Vacuolar degeneration has not been identified as a typical morphological feature in cells undergoing apoptosis (57). Thus, vacuolar degeneration and CD95-mediated apoptosis might represent two different mechanisms contributing to the toxic activity of $H$. pylori.

In conclusion, this study provides evidence that apoptosis is involved in $H$. pylori-induced epithelial cell damage. Apoptotic cell death in $H$. pylori-associated chronic gastritis may not only involve killing of epithelial cells by CD95L-expressing lymphocytes but also may occur by fratricide and/or suicide mediated by CD95L-CD95 interaction among gastric epithelial cells. The involvement of the CD95 pathway in $H$. pyloriinduced gastric epithelial apoptosis offers a new understanding of the pathogenesis of chronic H. pylori-induced gastritis.

\section{Acknowledgments}

The expert technical assistance of Jutta Mohr, Wolfgang Müller, Marlene Pach, Young-Gyu Park, and Bettina Reis is gratefully acknowledged. We wish to thank Dr. I. Zuna for performing the statistical analysis and Prof. P. Möller for critical reading of the manuscript.

This work was supported in part by a grant from Astra GmbH, Wedel, Germany.

\section{References}

1. NIH Consensus Conference. 1994. Helicobacter pylori in peptic ulcer disease. NIH Consensus development panel. J. Am. Med. Assoc. 272:65-69.

2. Marshall, B.J., and J.R. Warren. 1994. Unidentified curved bacilli in the stomach of patients with gastritis and peptic ulceration. Lancet. i:1311-1314.

3. Dixon, M.F., R.M. Genta, J.H. Yardley, P. Correa, and the International Workshop on the Histopathology of Gastritis, Houston 1994. 1996. Classification and grading of gastritis. The updated Sydney system. Am. J. Surg. Pathol. 20:1161-1181.

4. Fan, X.G., D. Kelleher, X.J. Fan, H.X. Xia, and P.W. Keeling. 1996. Helicobacter pylori increases proliferation of gastric epithelial cells. Gut. 38:19-22.

5. Robert, M.E., and W.M. Weinstein. 1993. Helicobacter pylori-associated gastric pathology. Gastroenterol. Clin. N. Am. 22:59-72.

6. Bursch, W., F. Oberhammer, and R. Schulte-Hermann. 1992. Cell death by apoptosis and its protective role against disease. Trends Pharmacol. Sci. 13: 245-251. 475 .

7. Evans, V.G. 1993. Multiple pathways to apoptosis. Cell. Biol. Int. 17:461-

8. Nagata, S. 1997. Apoptosis by death factor. Cell. 88:355-365.

9. Pickup, D.J., B.S. Ink, W. Hu, C.A. Ray, and W. Kinoklik. 1986. Hemorrhage in lesions caused by cowpox virus is induced by a viral protein that is related to plasma protein inhibitors of serine proteases. Proc. Natl. Acad. Sci. USA. 83:7698-7702.

10. White, E., P. Sabbatini, M. Debbas, W.S.M. Wold, D.I. Kusher, and L.R. Gooding. 1992. The $19 \mathrm{kD}$ adenovirus E1B transforming protein inhibits programmed cell death and prevents cytolysis by TNF. Mol. Cell. Biol. 12:25702580 .

11. Roberts, J.M., J.W. Searle, and W.G. Cooksley. 1993. Histological patterns of prolonged hepatitis C infection. Gastroenterology. 26:37-41.

12. Apasov, S., F. Redegeld, and M. Sitkovsky. 1993. Cell-mediated cytotoxicity: contact and secreted factors. Curr. Opin. Immunol. 5:404-410.

13. Rouvier, E., M.-F. Luciani, and P. Golstein. 1993. Fas involvement in $\mathrm{Ca}^{2+}$-independent T cell-mediated cytotoxicity. J. Exp. Med. 177:195-200.

14. Lowin, B., M. Hahne, C. Mattmann, and J. Tschopp. 1994. Cytolytic T-cell cytotoxicity is mediated through perforin and Fas lytic pathways. Nature. 370:650-652.

15. Kägi, D., F. Vignaux, B. Ledermann, K. Bürki, V. Depraetere, S. Nagata, H. Hengartner, and P. Golstein. 1994. Fas and perforin pathways as major mechanisms of T-cell-mediated cytotoxicity. Science. 265:528-530.

16. Kägi, D., B. Lermann, K. Bürki, P. Seiler, B. Odermatt, K.J. Olsen, E.R. Podack, R.M. Zinkernagel, and H. Hengartner. 1994. Cytotoxicity mediated by $\mathrm{T}$ cells and natural killer cells is greatly impaired in perforin-deficient mice. $\mathrm{Na}$ ture. 369:31-37.

17. Itoh, N., S. Yonehara, A. Ishii, M. Yonehara, S.I. Mizuchima, M. Sameshima, A. Hase, Y. Seto, and S. Nagata. 1991. The polypeptide encoded by the cDNA for human cell surface antigen Fas can mediate apoptosis. Cell. 66:
2333-2343.

18. Oehm, A., I. Behrmann, W. Falk, M. Pawlita, G. Maier, C. Klas, M. LiWeber, S. Richards, J. Dhein, B.C. Trauth, et al. 1992. Purification and molecular cloning of the APO-1 surface antigen, a member of the TNF/NGF receptor superfamily. J. Biol. Chem. 267:10709-10715.

19. Leithäuser, F., J. Dhein, G. Mechtersheimer, K. Koretz, S. Brüderlein, C. Henne, A. Schmidt, K.M. Debatin, P.H. Krammer, and P. Möller. 1993. Constitutive and induced expression of APO-1, a new member of the nerve growth factor/tumor necrosis factor receptor superfamily, in normal and neoplastic cells. Lab. Invest. 69:415-429.

20. Trauth, B.C., C. Klas, A.M.J. Peters, S. Matzku, P. Möller, W. Falk, K.M. Debatin, and P.H. Krammer. 1989. Monoclonal antibody-mediated tumor regression by induction of apoptosis. Science. 245:301-305.

21. Yonehara, S., A. Ishii, and M. Yonehara. 1989. A cell-killing monoclonal antibody (anti-Fas) to cell surface antigen co-downregulated with the receptor of tumor necrosis factor. J. Exp. Med. 169:1747-1756.

22. Suda, T., T. Takahashi, P. Golstein, and S. Nagata. 1993. Molecular cloning and expression of the Fas ligand, a novel member of the tumor necrosis factor family. Cell. 75:1169-1178.

23. Suda, T., and S. Nagata. 1994. Purification and characterization of the Fas-ligand that induces apoptosis. J. Exp. Med. 179:873-879.

24. Galle, P.R., W.J. Hofmann, H. Walczak, H. Schaller, G. Otto, W. Stremmel, P.H. Krammer, and L. Runkel. 1995. Involvement of the CD95 (APO-1/ Fas) receptor and ligand in liver damage. J. Exp. Med. 182:1223-1230.

25. Riley, L.K., C.L. Franklin, R.R. Hook, Jr., and C. Besch-Williford. 1996. Identification of murine Helicobacters by PCR and restriction enzyme analyses. J. Clin. Microbiol. 34:942-946.

26. Rudi, J., C. Kolb, M. Maiwald, D. Kuck, A. Sieg, and W. Stremmel. 1998. Diversity of Helicobacter pylori vacA and cagA genes and relationship to VacA and CagA expression, cytotoxin production, and associated diseases. $J$. Clin. Microbiol. 36:944-948.

27. Dhein, J., P.T. Daniel, B.C. Trauth, A. Oehm, P. Möller, and P.H. Krammer. 1992. Induction of apoptosis by monoclonal antibody anti-APO-1 class switch variants is dependent on cross-linking of APO-1 cell surface antigens. J. Immunol. 149:3166-3173.

28. Angerer, L.M., and R.C. Angerer. 1992. In situ hybridization to cellular RNA with radiolabeled RNA probes. In In Situ Hybridization. A Practical Approach. D.G. Wilkinson, editor. Oxford University Press, New York. 15-32.

29. Atherton, J.C., P. Cao, R.M. Peek, M.K.R. Tummuru, M.J. Blaser, and T.L. Cover. 1995. Mosaicism in vacuolating cytotoxin alleles of Helicobacter pylori. J. Biol. Chem. 270:17771-17777.

30. Peter, M.E., J. Dhein, A. Ehret, S. Hellbardt, H. Walczak, G. Moldenhauer, and P.H. Krammer. 1995. APO-1 (CD95)-dependent and -independent antigen receptor-induced apoptosis in human $\mathrm{T}$ and $\mathrm{B}$ cell lines. Int. Immunol. 7:1873-1877.

31. Wong, G.H.W., and D. Goeddel. 1994. Fas antigen and p55 TNF receptor signal apoptosis through distinct pathways. J. Immunol. 152:1751-1755.

32. Nicoletti, I., G. Migliorati, M.C. Paggliacci, F. Grignani, and C. Riccardi. 1991. A rapid and simple method for measuring thymocyte apoptosis by propidium iodide staining and flow cytometry. J. Immunol. Methods. 39:271-279.

33. Dhein, J., H. Walczak, C. Bäumler, K.M. Debatin, and P.H. Krammer 1995. Autocrine T-cell suicide mediated by APO-1 (Fas/CD95). Nature. 373: 438-441.

34. Moss, S.F., J. Calam, B. Agarwal, S. Wang, and P.R. Holt. 1996. Induction of gastric epithelial apoptosis by Helicobacter pylori. Gut. 38:498-501.

35. Mannick, E.E., L.E. Bravo, G. Zarama, J.L. Realpe, X.-J. Zhang, B. Ruiz, E.T.H. Fontham, R. Mera, M.J.S. Miller, and P. Correa. 1996. Inducible nitric oxide synthase, nitrotyrosine, and apoptosis in Helicobacter pylori gastritis: effect of antibiotics and antioxidants. Cancer Res. 56:3238-3243.

36. Peek, R.M., S.F. Moss, and K.T. Tham. 1997. Helicobacter pylori cagA+ strains and dissociation of gastric epithelial cell proliferation from apoptosis. $J$. Natl. Cancer Inst. 89:863-868.

37. Vignaux, F., and P. Golstein. 1994. Fas-based lymphocyte-mediated cytotoxicity against syngeneic activated lymphocytes: a regulatory pathway? Eur. J. Immunol. 24:923-927.

38. Mita, E., N. Hayashi, S. Iio, T. Takehara, T. Hijioka, A. Kasahra, H. Fusamoto, and T. Kamada. 1994. Role of Fas ligand in apoptosis induced by hepatitis C virus infection. Biochem. Biophys. Res. Commun. 204:468-474.

39. Giordano, C., G. Stassi, R. De Maria, M. Todaro, P. Richiusa, G. Papoff, G. Ruberti, M. Bagnasco, R. Testi, and A. Galluzo. 1997. Potential involvement of Fas and its ligand in the pathogenesis of Hashimoto's thyroiditis. Science. 275:960-963.

40. Strand, S., W.J. Hofmann, H. Hug, M. Müller, G. Otto, D. Strand, S.M Mariani, W. Stremmel, P.H. Krammer, and P.R. Galle. 1996. Lymphocyte apoptosis induced by CD95 (APO-1/Fas) ligand-expressing tumor cells: a mechanism of immune evasion? Nat. Med. 2:1361-1366.

41. Tanaka, M., T. Itai, M. Adachi, and S. Nagata. 1998. Downregulation of Fas ligand by shedding. Nat. Med. 4:31-36.

42. Crabtree, J.E., T.M. Shallcross, R.V. Heatley, and J.I. Wyatt. 1991. Mucosal tumour necrosis factor alpha and interleukin-6 in patients with Helicobacter pylori associated gastritis. Gut. 32:1473-1477.

43. Moss, S.F., S. Legon, J. Davies, and J. Calam. 1994. Cytokine gene ex- 
pression in Helicobacter pylori associated antral gastritis. Gut. 35:1567-1570.

44. Genta, R.M. 1997. The immunobiology of Helicobacter pylori gastritis. Semin. Gastrointest. Dis. 8:2-11.

45. Wagner, S., W. Beil, J. Westermann, R.P.H. Logan, C.T. Bock, C. Trautwein, J.S. Bleck, and M.P. Manns. 1997. Regulation of gastric epithelial cell growth by Helicobacter pylori: evidence for a major role of apoptosis. Gastroenterology. 113:1836-1847.

46. Cover, T.L., C.P. Dooley, and M.J. Blaser. 1990. Characterization of and human serologic response to proteins in Helicobacter pylori broth culture supernatants with vacuolizing cytotoxin activity. Infect. Immun. 58:603-610.

47. Smoot, D.T., J.H. Resau, M.H. Earlington, M. Simpson, and T.L. Cover. 1996. Effects of Helicobacter pylori vacuolating cytotoxin on primary cultures of human gastric epithelial cells. Gut. 39:795-799.

48. Harris, R.P., T.L. Cover, D.R. Crowe, J.M. Orenstein, M.F. Graham, M.J. Blaser, and P.D. Smith. 1996. Helicobacter pylori cytotoxin induces vacuolation of primary human mucosal epithelial cells. Infect. Immun. 64:4867-4871.

49. Cover, T.L., P. Cao, C.D. Lind, K.T. Tham, and M.J. Blaser. 1993. Correlation between vacuolating cytotoxin production by Helicobacter pylori isolates in vitro and in vivo. Infect. Immun. 61:5008-5012.

50. Censini, S., C. Lange, Z. Xiang, J.E. Crabtree, P. Ghiara, M. Borodovsky, R. Rappuoli, and A. Covacci. 1996. cag, a pathogenicity island of Helicobacter pylori, encodes type I-specific and disease-associated virulence factors. Proc. Natl. Acad. Sci. USA. 93:14648-14653.

51. Tummuru, M.K., S.A. Sharma, and M.J. Blaser. 1995. Helicobacter py- lori picB, a homologue of the Bordetella pertussis toxin secretion protein, is required for induction of IL-8 in gastric epithelial cells. Mol. Microbiol. 18:867876.

52. Peek, R.M., G.G. Miller, K.T. Tham, G.I. Perez-Perez, X. Zhao, J.C Atherton, and M.J. Blaser. 1995. Heightened inflammatory response and cytokine expression in vivo to cagA + Helicobacter pylori strains. Lab. Invest. 71: 760-770.

53. Yamaoka, Y., M. Kita, T. Kodama, N. Sawai, and J. Imanishi. 1996 Helicobacter pylori cagA gene and expression of cytokine messenger RNA in gastric mucosa. Gastroenterology. 110:1744-1752.

54. Sharma, S.A., M.K. Tummuru, G.G. Miller, and M.J. Blaser. 1995. Interleukin-8 response of gastric epithelial cell lines to Helicobacter pylori stimulation in vitro. Infect. Immun. 63:1681-1687.

55. Piotrowski, J., D. Skrodzka, A. Slomiany, and B.L. Slomiany. 1996. Helicobacter pylori lipopolysaccharide induces gastric epithelial cell apoptosis. Biochem. Mol. Biol. Int. 40:597-602.

56. Papini, E., E. Gottardi, B. Satin, M. De Bernhard, P. Massari, J. Telford, R. Rappuoli, S.B. Sato, and C. Montecucco. 1996. The vacuolar ATPase proton pump is present on intracellular vacuoles induced by Helicobacter pylori. J. Med. Microbiol. 45:84-89.

57. Kerr, J.F., A.H. Wyllie, and A.R. Curries. 1972. Apoptosis: a basic biological phenomenon with wide-ranging implications in tissue kinetics. $\mathrm{Br} . J$. Cancer. 26:239-257. 